\title{
Complexities of Oral Antiplatelet Drugs Use in Pregnancy
}

\author{
Nebojša M. Antonijevićn ${ }^{1,2}$, Nikola D. Gošnjićs ${ }^{3}$ Ivan V. Ranković ${ }^{4}$, \\ Ljubica M. Jovanović ${ }^{1}$, Ivana D. Veljić ${ }^{1}$, Dragan M. Matićc ${ }^{1,2}$, \\ Mladen J. Kočica ${ }^{5,7}$, Milica M. Karadžić Kočica ${ }^{6}$, Branka M. Terzić ${ }^{1}$, \\ Žaklina V. Leković ${ }^{1}$, Dario D. Jelić ${ }^{1}$, Vladimir I. Kanjuh ${ }^{7}$ \\ ${ }^{1}$ Clinic for Cardiology, Clinical Center of Serbia, Belgrade, Serbia \\ ${ }^{2}$ Faculty of Medicine, University of Belgrade, Belgrade, Serbia \\ ${ }^{3}$ Department of Pharmacokinetics and Clinical Pharmacy, Faculty of Pharmacy, University of \\ Belgrade, Belgrade, Serbia \\ ${ }^{4}$ Clinic for Gastroenterology and Hepatology, Clinical Center of Serbia, Belgrade, Serbia \\ ${ }^{5}$ Emergency Centre Clinical Centre of Serbia, Clinic for Cardiac Surgery, Belgrade, Serbia \\ ${ }^{6}$ Emergency centre Clinical Centre of Serbia, Clinic for Cardiac Surgery, Department of Anes- \\ thesiology, Reanimatology and Intensive Care, Belgrade, Serbia \\ ${ }^{7}$ Serbian Academy of Sciences and Arts, Board on Cardiovascular Pathology, Belgrade, Serbia
}

\section{SUMMARY}

Introduction: Given the increasing occurrence of pregnancy at a relatively older age in the current clinical practice, many therapeutic approaches characteristically used in the elderly population are becoming an important consideration point for the clinicians.

Antiplatelet drugs: The safety of antiplatelet drug administration in pregnancy should be brought into a sharper focus regarding both mother and child. It is a complex clinical task since the pregnancy is followed by many changes potentially affecting the drug choice - increased blood coagulability, changes in platelet aggregation, and pharmacokinetic alternations of the drug itself. Acetylsalicylic acid, as the most commonly used antiplatelet drug, appears to be mostly safe and effective for mother and fetus in many conditions occurring during pregnancy when used in low doses. However, although considered generally safe, its use requires careful approach due to many drug and pregnancy specificities. On the other hand, evidence showing adequate clinical use of P2Y12 receptor antagonists (clopidogrel, ticagrelor, prasugrel, and ticlopidine) are scarce. Cases showing their use in clinical practice are emerging and the future practice and treatment approach might be changed with the new cases becoming available.

Conclusion: Regardless of the drug, pregnancy itself and any indication for the treatment used in this patient population are typically complex and require well-coordinated management by the interdisciplinary clinical team.

Keywords: pregnancy, acetylsalicylic acid, antiplatelet, P2Y12 antagonist

Corresponding authors:

Academic Professor Vladimir I. Kanjuh, MD, PhD

Serbian Academy of Sciences and Arts, Board on Cardiovascular Pathology, Knez Mihailova 35, Belgrade, Serbia

E-mail: kanjuh@eunet.rs 


\section{INTRODUCTION}

Considering the increase of the relatively older population of pregnant women the use of antiplatelet therapy in pregnancy is an important discussion point for the clinicians $[1,2]$. The most often indications for the use of these drugs in pregnancy are: angina pectoris, myocardial infarction, ischemic cerebrovascular insult, additional therapy for the prevention of mechanical valves thrombosis or as a monotherapy in case of biological heart valves three months after surgery (acetylsalicylic acid only), preeclampsia, prevention of the placental thrombosis and miscarriage, intrauterine growth restriction (IUGR) associated with placental insufficiency, antiphospholipid syndrome, sticky platelets syndrome, thrombophilia, and secondary prophylaxis after coronary bypass surgery $[1,3,4,5]$.

Description of all the changes occurring in the pregnancy that may affect the choice of the drug is out of the scope of this article but clinicians should always be aware of the common pharmacokinetic changes such as an increase in the activity of liver enzymes, increased degree of glomerular filtration, increase in plasma volume, changes in protein binding and reduction of serum albumin levels [1]. Besides these changes, various risk factors such as smoking [6], hypertension, diabetes, dyslipidemia, thrombophilia, infections, etc. that may cause cardiovascular pathologies in pregnant women should also be assessed on an individual patient basis [1].

The following text provides a review of the most commonly used antiplatelet medicines focusing on their efficacy and safety when used in pregnancy and lactation.

The description of each presented drug given in the following text will reflect on the previously used pregnancy categories developed by the Food and Drug Administration (FDA). Meaning of each such category is shown in the Table 1. [7].

It should be emphasized that although these categories may be useful for initial clinical decision making, their use should always be done only considering the complete clinical setting of each patient individually. For this reason, FDA recommended that these categories should be replaced with a complete drug information, which describes different and complex nature of each drug when used on the pregnancy, leaving the final decision on the prescriber [8].

\section{ANTIPLATELET DRUGS}

\section{Acetylsalicylic acid}

The safety of both mother and fetus should be observed when considering the use of acetylsalicylic acid in pregnancy (FDA classified it in the category D) given that acetylsalicylic acid crosses placental barrier [9].

The large meta-analysis which included 32217 pregnant women showed that the use of $50-150 \mathrm{mg}$ of acetylsalicylic acid as a monotherapy ( $98 \%$ of women whereas the rest used combined therapy with dipyridamole) does not pose a statistically significant greater risk of developing postpartum hemorrhage in mother. Namely, postpartum hemorrhage (defined as bleeding equal to or greater than $500 \mathrm{ml}$ ) occurred in $15 \%$ of patients, regardless if they used acetylsalicylic acid or not [10]. Similar to the aforementioned results, the
Table 1. FDA pregnancy categories
Pregnancy category

A

B

C

D

$X$

\section{Description}

Adequate and well-controlled studies have failed to demonstrate a risk to the fetus. Potential for harm is minimal.

There are no adequate studies in humans, but animal reproduction studies have failed to demonstrate a risk to the fetus.

Although animal reproduction studies have shown an adverse effect on the fetus and there are no adequate and well-controlled studies in humans, potential benefits of the use in clinical settings may outweigh the risk of the use.

Positive evidence of the risk on humans is evident and studies both in humans and in animals have shown potential harm. However, they can be used in potentially life-threatening states and if there is no safer alternative.

Contraindicated in pregnancy. Animal and post-marketing studies have shown that negative effects on the fetus outweigh the benefit. 
large review article shows that the use of low doses of acetylsalicylic acid or dipyridamole in 25806 pregnant women does not carry a statistically significant greater risk of placenta abruption when compared to placebo [11].

Based on the results obtained more than twenty years ago in the big, randomized, double-blinded study the use of low doses of acetylsalicylic acid $(60 \mathrm{mg})$ as a treatment for preeclampsia was found to be safe from the aspect of congenital malformations, major motor deficit, and severe neuromotor or developmental delay both during pregnancy and in early childhood [12].

However, it should be emphasized that the doses of $60 \mathrm{mg}$ of acetylsalicylic acid, although used in the aforementioned study are not readily available as the low-dose acetylsalicylic acid is typically sold in the dosages of 75 $\mathrm{mg}, 81 \mathrm{mg}$, and $100 \mathrm{mg}$. Another potentially interesting dosage form, although not studied in the pregnancy, might be intravenous acetylsalicylic acid which provides more rapid and consistent platelet inhibition compared to oral acetylsalicylic acid [13]. Of note, it is considered that dose as low as $50 \mathrm{mg}$ used daily may be sufficient for the anti-thrombotic effect [14].

One of the biggest clinical dilemmas when considering the use of acetylsalicylic acid is its effect on the closure of ductus arteriosus. The research which studied the effect of acetylsalicylic acid on the antenatal closure of ductus arteriosus was in situ study on 511 stillborn, where 15 was found to have premature closure of ductus arteriosus. However, the study concluded that acetylsalicylic acid was not a cause in any of these cases, but that they occurred as a combination of various factors - intrauterine infection (60\%), umbilical cord abnormalities (67\%), and retroplacental hem- orrhage (87\%) Besides, Doppler blood flow measurement was also used in other studies to assess the blood flow through fetal ductus arteriosus [15]. One such study analyzed blood flow in 106 pregnancies in which acetylsalicylic acid was not used and in 65 where the low dose of acetylsalicylic acid (80 mg or 100 $\mathrm{mg}$ ) was taken during the pregnancy. The result indicated no hemodynamic changes in the ductus arteriosus [16].

Besides being relatively safe in pregnancy, acetylsalicylic acid is also effective in achieving better pregnancy outcomes, especially in conditions such as preeclampsia which presents one of the most common indications for the use of acetylsalicylic acid in this patient population. A recent meta-study included the results of 3168 pregnancies from the randomized clinical trials. Acetylsalicylic acid was used in the early stages (week 16 or earlier) of pregnancies, which carried the risk of preeclampsia. Results indicated that such use of acetylsalicylic acid positively affected adverse pregnancy outcomes, both for mother (gestational hypertension and premature delivery) and for the newborn (intrauterine growth retardation, intrauterine death and decreased baby weight and development). A subgroup of 864 babies born by the mother of higher preeclampsia risk had 110.44 grams higher body weight when acetylsalicylic acid was compared to placebo [17].

However, besides previously mentioned results that present the safe use of low acetylsalicylic acid doses in pregnancy, a meta-analysis that included eight studies showed that the use of acetylsalicylic acid during the first pregnancy trimester may cause more often gastroschisis in the exposed babies. On the other hand, we stress out that the adequacy of included studies is debatable. In one of eight

\section{Guideline/Comment}

Low dose acetylsalicylic acid (100-150 mg daily) has been recommended for pregnant women with a moderate to high risk of developing preeclampsia from $12^{\text {th }}$ to $36^{\text {th }}$ or $37^{\text {th }}$ weeks.

In patients with coronary artery disease treated with stent implantation, acetylsalicylic acid in combination with clopidogrel represents the antiplatelet therapy of choice.

The addition of low dose acetylsalicylic acid to vitamin $\mathrm{K}$ antagonists or heparins in pregnant women with prosthetic valves has no proven advantage in preventing valvular thrombosis, but may contribute to the risk of maternal bleeding, including fatal side effects.
Indication

Hypertension
and

pre-eclampsia

Coronary artery

disease

Prophylaxis in mechanical prostheses
Class of Level of Evidence Evidence
Table 2. ESC guidelines for the use of acetylsalicylic acid in pregnancy

Classes of recommendation: Class I - Evidence and/or general agreement that a given treatment or procedure is beneficial, useful, effective.

Level of evidence:

A - Data derived from multiple randomized clinical trials or meta-analyses 
of these studies, the mothers were of low socioeconomic status and abused some drugs. Other antipyretics may have caused the gastroschisis in other studies, whereas in two more of the analyzed studies the problem of objectivity was stressed out as the healthy babies were used as a control group [18].

Some studies imply that the use of acetylsalicylic acid during pregnancy may lead to orofacial cleft (cleft lip and cleft palate). Although such risk cannot be completely disregarded, the study examining reports from the Hungarian national registry of congenital anomalies in 3415 babies showed that orofacial cleft was not more common in newborns whose mothers used acetylsalicylic acid during pregnancy. The same study showed similar results for neural tube defects and gastroschisis [19]. It should be underlined that the problem of assessing the results of the aforementioned study is the lack of information regarding the dose and duration of acetylsalicylic acid treatment.

Based on the available safety and efficacy data the competent organizations developed clinical guidelines regarding the use of acetylsalicylic acid in pregnancy. Guidelines from the European Society of Cardiology (ESC) are presented in the table 2 [1].

Besides previously mentioned European guidelines, American College of Chest Physicians (ACCP) also gives set of recommendations for the use of acetylsalicylic acid during pregnancy that can be seen in table 3 [20].

From the perspective of the population presented in this article, we would also like to mention the assisted reproductive technology (ART) as the common indication for the use of acetylsalicylic acid in women. For this indication, low doses of acetylsalicylic acid are used for varying duration. However, despite the wide use in this technique, evidence supporting its effectiveness for the primary end outcome of live births was not shown in the recent systematic review that collected data from the thirteen randomized clinical trials involving a total of 2653 participants [21].

Although not specific for the population of pregnant women, the possible adverse effect of acetylsalicylic acid is upper gastrointestinal toxicity. Studies conducted specifically in pregnant women regarding the gastrointestinal toxicity were not identified, but data from the general population is available. A study which included 10000 subjects, of which 8106 agreed to participate has shown that upper gastrointestinal symptoms occurred in $15.4 \%$ of patients receiving low dose acetylsalicylic acid (doses ranging from 75 to $325 \mathrm{mg}$ ). The most common complaint was gastroesophageal reflux, accounting for up to $70 \%$ of reports [22]. Despite presenting this kind of data we suggest using clinical judgement. The most important predictor of possible gastrointestinal adverse effects was prior history of dyspeptic disorders. Furthermore, although discontinuation of acetylsalicylic acid may attenuate gastrointestinal complaints, in patients with significant cardiovascular disease risk it increases the risk of all-cause mortality [23].

Commonly used prophylactic treatment for the gastrointestinal symptoms caused by acetylsalicylic acid are proton pump inhibitors (PPI). A recent meta-analysis showed that PPI may carry an increased risk of causing congenital malformations of the fetus. However, such malformations were not specified, and it was shown that their use does not correlate with miscarriage, neonatal death, and preterm delivery [24]. When taken in the early stages of pregnancy, PPI are considered to possibly cause either early or late preeclampsia. Interestingly if used after $28^{\text {th }}$ week of gestation, these drugs decreased the risk of developing preterm (earlier than $37^{\text {th }}$ pregnancy week) or early (earlier than $34^{\text {th }}$ pregnancy week) preeclampsia, which may be a consideration for
Table 3. ACCP guidelines for the use of acetylsalicylic acid in pregnancy

\section{Grading scheme:}

Grade 1 - Strong recommendation;

Grade 2 - Weak recommendation.

Level of Evidence:

Grade B - Moderate;

Grade C - Low.

\section{Guideline/Comment \\ For pregnant women with prosthetic valves and a high risk of thromboembolism, the addition of low doses of acetylsalicylic acid (75-100 mg daily) has been recommended}

For pregnant women who meet the diagnostic criteria of antiphospholipid syndrome, the addition of low doses of acetylsalicylic acid (75-100 $\mathrm{mg}$ per day) with prophylactic use of heparin has been recommended

For pregnant women at risk of preeclampsia, the use of low doses of acetylsalicylic acid has been recommended, starting from the second trimester

\begin{tabular}{|c|c|}
\hline $\begin{array}{c}\text { Indication } \\
\text { Prophylaxis of } \\
\text { mechanical } \\
\text { prostheses thrombosis }\end{array}$ & Grade \\
\hline $\begin{array}{c}\text { Antiphospholipid } \\
\text { syndrome }\end{array}$ & 1B \\
\hline
\end{tabular}

Pre-eclampsia 1B 
their future use [25].

Although not specifically studied in pregnant women surgeries, acetylsalicylic acid may be considered for use in venous thromboembolism prophylaxis in persons with a lower thrombotic risk during orthopedic surgery, bearing in mind that anticoagulant drugs are key to VTE prevention [26, 27].

As a conclusion, although acetylsalicylic acid is generally safe in pregnancy, because it crosses the placenta [28] and all other specificities of the given population and the drug itself, its use requires a careful approach.

\section{$\mathrm{P}_{2 \mathrm{Y}_{12}}$ receptor antagonists}

Percutaneous Coronary Intervention (PCI) is the treatment of choice in patients with ongoing signs of ischemia and coronary artery disease, or in those in whom a large, viable myocardial territory is at risk, such as proximal LAD disease [29]. As the PCI is a standard treatment approach of coronary artery disease, the widespread use of dual antiplatelet therapy (DAPT) consisting of acetylsalicylic acid and another antiplatelet drug (most often P2 $\mathrm{Y}_{12}$ receptor antagonists) in pregnant women has become more prevalent $[30,31]$. Such therapeutic choice may be associated with both higher efficacy but also with the higher bleeding risk. Although not often used in daily clinical practice, platelet function test may help guide the safe use of antiplatelet drugs [32, 33].

\section{Clopidogrel}

Although key clopidogrel clinical trials excluded pregnant women its use is considered adequate when dual antiplatelet therapy is indicated, considering mostly uneventful case reports reported in the literature.

According to the Summary of Product Characteristics for clopidogrel, neither direct or indirect detrimental effects on the pregnancy course, embryonal, fetal or postnatal development were shown in animal studies. Although SmPC states that clopidogrel is not recommended in pregnant women due to lack of randomized trials, based on the current publications (until June of 2020) clopidogrel is considered to be the safest and the most often used drug from the group of ADP inhibitors [34]. It was categorized as Category B by the FDA [9]. In the further text, we give a short description of several clinical case reports.

A less recent case study reported the complications in the fetus or the newborn, which could not be clearly related to clopidogrel use. The case describes a thirty-nine-yearold pregnant woman who experienced myocardial infarction in the sixth week of gestation and was treated with percutaneous coronary intervention with the use of acetylsalicylic acid and clopidogrel until delivery. The baby was born with open foramen ovale $(0,2 \mathrm{~mm})$, restrictive communication of interventricular muscles and moderate mitral insufficiency [35].

On the other hand, a review of more recent articles published in the last five years describes a case where the clopidogrel was used during pregnancy as secondary prevention of the stroke where the drug was discontinued one week prior to delivery. Toxicity was observed neither for the mother nor for the newborn [36]. In addition, in another case clopidogrel was used as a treatment of acute myocardial infarction, but the toxicity could not be assessed due to elective abortion [37]. Additional case report identified during the literature search shows a 36 years old pregnant woman experiencing myocardial infarction 7 months before becoming pregnant. After implantation of a bare metal stent, dual antiplatelet therapy consisting of acetylsalicylic acid $100 \mathrm{mg}$ and clopidogrel $75 \mathrm{mg}$ was started. However, due to restenosis, the patient suffered another episode of angina due to which drug-eluting stent (DES) was implanted. Seven months after the first event, the patient became pregnant and was admitted to the hospital where it was decided that acetylsalicylic acid and clopidogrel are to be continued up to one year after DES implantation. One week prior to delivery, acetylsalicylic acid and clopidogrel were discontinued and replaced with low molecular weight heparin until the delivery. Successful caesarian section was performed and a healthy child was born [38].

In addition to previously mentioned case reports, a recent review article also shows that no reports of fetal or neonatal hemorrhage have been observed so far, mentioning the best practice of discontinuing clopidogrel 7 days prior to scheduled delivery [9].

According to current recommendations of the European Society of Cardiology, the use of clopidogrel is allowed in pregnancy as a treatment of acute myocardial infarction for the shortest possible period and in case other treatments cannot be used [1]. 
However, variability and resistance to the use of clopidogrel, one of the most common problems encountered with the use of this drug, have prompted clinicians to prescribe more potent P2Y12 inhibitors such as ticagrelor and prasugrel [39] which are described in the following sections.

\section{Ticagrelor}

Given the fact that ticagrelor and prasugrel represent drugs of choice compared to clopidogrel in patients initially treated with PCI (both stent placement or balloon angioplasty) [40], cases describing their successful use in pregnancy are being described, even though ticagrelor is not recommended during the pregnancy according to the summary of product characteristics [41]. FDA categorized ticagrelor in the Category C [42].

During the literature search, we have identified two such cases. The first one shows the female patient with the history of Behcet disease experiencing non-ST myocardial infarction treated with implantation of a drugeluting stent through percutaneous coronary intervention with dual antiplatelet therapy consisting of acetylsalicylic acid and ticagrelor. Dual antiplatelet therapy was used for one year - acetylsalicylic acid in the dose of $80 \mathrm{mg}$ and ticagrelor in the dose of $180 \mathrm{mg}$ (2x90 $\mathrm{mg})$. Despite the opposite recommendations, the patient became pregnant and decided to continue with the pregnancy. During the pregnancy the patient was treated with prednisolone $(8 \mathrm{mg})$, acetylsalicylic acid $(80 \mathrm{mg})$, and bisoprolol (5mg), all administered once daily. Besides these drugs, the patient also received ticagrelor in the dose of $180 \mathrm{mg}(2 \times 90 \mathrm{mg})$ daily, with the plan of continuing it for eight months and discontinuation seven days prior to planned delivery. The patient had regular examinations without any abnormal findings. Ticagrelor therapy was managed according to the described plan, being discontinued seven days prior to delivery. The delivery was inducted and a healthy baby was born, weighing $2645 \mathrm{~g}$. After the delivery, histology testing of the placenta was performed and no lesions were identified. However, iron-loaded macrophages in the decidua were observed, indicating antenatal hemorrhage which was not clinically detectable [42].

The other, more recent report of the use of ticagrelor during pregnancy presents the woman developing acute myocardial in- farction in the twenty-seventh week of gestation. After confirming the infarction, the patient was treated with intravenous acetylsalicylic acid $(500 \mathrm{mg})$, enoxaparin (10 000 $\mathrm{IU})$, and a loading dose of ticagrelor (180 mg). Afterwards, two sirolimus-eluting stents were placed. Considering the high thrombotic burden, unfractionated heparin in combination with tirofiban was introduced until achieving TIMI 3 flow. The patient was discharged with dual antiplatelet therapy consisting of acetylsalicylic acid and ticagrelor. After twelve weeks, the patient was admitted to the hospital in order to have the Caesarean section performed. In accordance with the recommendations on perioperative management of $\mathrm{P} 2 \mathrm{Y}_{12}$ antagonists[35], dual antiplatelet therapy with ticagrelor was discontinued five days prior to delivery and bridging therapy with tirofiban was administered (intravenous tirofiban in the dose of $0,4 \mathrm{mg} / \mathrm{kg} / \mathrm{min}$ during 30 minutes, followed by $0,1 \mathrm{mg} / \mathrm{kg} / \mathrm{min}$ for the next 96 hours until 4 hours prior to delivery). Cesarean section was performed without any complications and a healthy baby was born (body mass 3200 g). Subtotal hysterectomy for the atonic postpartum hemorrhage was also performed. Tirofiban was continued two hours after the surgery and stopped after ten hours, at which time dual antiplatelet therapy with the loading dose of $180 \mathrm{mg}$ of ticagrelor was reintroduced. The patient was advised to continue dual antiplatelet therapy for one year. Twenty-seven weeks after delivery the patient was followed up and both her and the baby were in good condition without any health issues [43]. With the shown cases, we would like to stress out that up to the date of this publication all clinicians opted for the discontinuation of ticagrelor and bridging the therapy with GP IIb/IIIa antagonists, following the recommendations of ESC, although the physician may make appropriate changes to the given recommendations taking into consideration the type of the surgery and the current clinical course the patient has.

Despite previously described positive experience with the use of ticagrelor, the European Society of Cardiology advises against its use in pregnant women until more information is available [1].

\section{Prasugrel}

According to the Summary of Product Characteristics for Prasugrel, its use in pregnancy 
is not recommended unless other treatment cannot be used. Similar to ticagrelor, clinical studies which would give detailed information regarding its use in this population are lacking, although animal studies have not shown negative effects on embryonal, fetal or postnatal development [44]. It was categorized in Category B by the FDA [9]. However, although its routine use is not recommended in pregnancy if there are alternative treatment options, one individual case report that will be presented in the future text has been described in the scientific literature. In this report, Prasugrel was used as a part of dual antiplatelet therapy in combination with acetylsalicylic acid after implantation of two drug-eluting stents. The initial dose of the administered prasugrel was $60 \mathrm{mg}$ with a maintenance dose of $10 \mathrm{mg}$ daily, whereas acetylsalicylic acid was given in the dose of $81 \mathrm{mg}$ daily. The patient was diagnosed with pregnancy one month later. Despite insufficient information regarding the use of prasugrel in pregnancy, the patient refused the abortion and continued her pregnancy concomitantly using dual antiplatelet therapy. The delivery was performed by Caesarean section after dual antiplatelet therapy had been discontinued for five days before the surgery [45]. We point out that European Society of Cardiology recommends discontinuing prasugrel seven days prior to surgery [40]. Normal-phenotype baby weighing $2500 \mathrm{~g}$ was born without hemorrhage or signs of any malformations whatsoever. The mother also had not experienced any complications so the dual antiplatelet therapy was continued in the aforementioned maintenance regimen [45]. However, despite the described positive experience, the European Society of Cardiology still does not recommend the use of prasugrel in pregnancy, until evidence supporting its safe use emerges [1].

\section{Ticlopidine}

Ticlopidine was one of the first used P2Y antagonists. However, it is nowadays seldom used due to rare but possible serious adverse effects such as neutropenia/agranulocytosis, thrombotic thrombocytopenic purpura and aplastic anemia [46]. Another reason for the more often use of the new $\mathrm{P}_{2} \mathrm{Y}_{12}$ receptor antagonists over the ticlopidine is its slower onset of action [47]. It was categorized as category D by the FDA [9].

We have identified only one recent article regarding the use of ticlopidine in pregnancy. This case presents a woman with a mechanic aortic valve on warfarin therapy presenting with the intention of becoming pregnant. For this reason, warfarin was discontinued and replaced with dipyridamole $300 \mathrm{mg} /$ day, ticlopidine $300 \mathrm{mg} /$ day, and acetylsalicylic acid $81 \mathrm{mg} /$ day. The patient was admitted in the $36^{\text {th }}$ week of pregnancy when these antiplatelet drugs were discontinued and heparin was introduced. Cesarean section without complications was performed at week 38 of gestation and a healthy baby was delivered [48].

However, since safer alternatives with more rapid onset of action are available, ticlopidine is not commonly used in clinical practice.

\section{CONCLUSION}

The use of antiplatelet therapy requires well informed clinical judgement. When considering the above medication clinicians should always evaluate the dosage regimen and the duration of therapy based on the summary of product characteristics, appropriate guidelines, and current clinical experiences. Furthermore, understanding of the risk for the mother and fetus on the one side and the potential benefit on the other may guide their adequate use. According to our study acetylsalicylic acid remains the mainstay drug among antiplatelets due to long clinical experience. Clopidogrel can be considered as an alternative when indicated, as the probably safest option in the class of $\mathrm{P} 2 \mathrm{Y}^{12}$ antagonists. However, as presented in this review, in certain delicate cases clinicians may opt to use other $\mathrm{P} 2 \mathrm{Y}^{12}$ antagonists. Indications for their use in pregnancy are typically complex and should be managed by the interdisciplinary clinical team. As the evidence regarding more potent antiplatelet drugs emerges, the current practice may follow the fast development and the need for the use of more potent antiplatelets.

\section{CONFLICT OF INTEREST}

All authors declare no conflict of interest.

\section{REFERENCES}

1. Regitz-Zagrosek V, Roos-Hesselink JW, Bauersachs J, Blomström-Lundqvist C, Cífková R, De Bonis $M$, et al. 2018 ESC Guidelines for the management of cardiovascular diseases during pregnancy. European 
Heart Journal. 2018 Sep 7;39(34):3165-241.

2. Antonijević NM, Jovanović LjM, Terzić BM, Kovač MK, Ilić Mostić TŽ, Živković ID, Matić DM, Lasica RM, Ranković IV, Radovanović NL, Ašanin MR, Kanjuh VI. Anticoagulation in Pregnancy and Puerperium: With a Focus on the Benefits and Risks of the Applications of Vitamin K Antagonists on the Prevention of Mechanical Heart Valves Thrombosis. Hospital Pharmacology - International Multidisciplinary Journal. 2016; 3(1):328-340. (www.hophonline.org) doi:10.5937/hpimj1601328A

3. Kubisz P, Stanciakova L, Stasko J, Dobrotova M, Skerenova M, Ivankova J, Holly P. Sticky platelet syndrome: an important cause of life-threatening thrombotic complications. Expert Review of Hematology. 2016 Jan 2;9(1):21-35.

4. McCowan LM, Figueras F, Anderson NH. Evidencebased national guidelines for the management of suspected fetal growth restriction: comparison, consensus, and controversy. American Journal of Obstetrics and Gynecology. 2018 Feb;218(2):S855S868.

5. Hong $\mathrm{Li} \mathrm{Y}$, Marren A. Recurrent pregnancy loss: A summary of international evidence-based guidelines and practice. Aust J Gen Pract. 2018 $07 ; 47(7): 432-6$.

6. Dubljanin J, Uštević Č, Gošnjić N, Pejić N, Ranković I, Jovanović LJ, Leković Ž, Veljić I, Antonijević N, Kanjuh V. Patogenetski mehanizmi indukcije ubrzane ateroskleroze kod pušača. Srce i krvni sudovi 2020 (In press)

7. Content and Format of Labeling for Human Prescription Drug and Biological Products; Requirements for Pregnancy and Lactation Labeling (Federal Register/Vol. 73, No. 104/Thursday, May 29, 2008)

8. Pregnancy, Lactation, and Reproductive Potential: Labeling for Human Prescription Drug and Biological Products - Content and Format Guidance for Industry, draft guidance version. U.S. Department of Health and Human Services, Food and Drug Administration. Center for Drug Evaluation and Research (CDER) , Center for Biologics Evaluation and Research (CBER) July 2020 Labeling Revision 1.

9. Yarrington CD, Valente AM, Economy KE. Cardiovascular Management in Pregnancy. Circulation. 2015 Oct 6;132(14):1354-64.

10. Askie LM, Duley L, Henderson-Smart DJ, Stewart LA. Antiplatelet agents for prevention of preeclampsia: a meta-analysis of individual patient data. Lancet. 2007 May 26;369(9575):1791-8.

11. Duley L, Henderson-Smart DJ, Meher S, King JF. Antiplatelet agents for preventing pre-eclampsia and its complications. Cochrane Database Syst Rev. 2007 Apr 18; Issue 2. Art. No.: CD004659.

12. Low dose aspirin in pregnancy and early childhood development: follow up of the collaborative low dose aspirin study in pregnancy. CLASP collaborative group. $\mathrm{Br} \mathrm{J}$ ObstetGynaecol. 1995 Nov;102(11):861-8.

13. Nagelschmitz J, Blunck M, Kraetzschmar J, Ludwig $M$, Wensing $G$, Hohlfeld T. Pharmacokinetics and pharmacodynamics of acetylsalicylic acid after intravenous and oral administration to healthy volunteers. Clin Pharmacol. 2014;6:51-9.

14. Warner TD, Nylander S, Whatling C. Anti-platelet therapy: cyclo-oxygenase inhibition and the use of aspirin with particular regard to dual anti-platelet therapy. British Journal of Clinical Pharmacology. 2011 Oct;72(4):619-33.

15. Wyatt-Ashmead J. Antenatal closure of the ductus arteriosus and hydrops fetalis. Pediatr Dev Pathol. 2011 Nov-Dec;14(6):469-74.

16. Miyazaki M, Kuwabara Y, Takeshita T. Influence of perinatal low-dose acetylsalicylic acid therapy on fetal hemodynamics evaluated by determining the acceleration-time/ejection-time ratio in the ductus arteriosus. J Obstet Gynaecol Res. 2018 Jan;44(1):87-92.

17. Cui $Y$, Zhu B, Zheng F. Low-dose aspirin at $\leq 16$ weeks of gestation for preventing preeclampsia and its maternal and neonatal adverse outcomes: A systematic review and meta-analysis. Exp Ther Med. 2018 May;15(5):4361-9.

18. Kozer E, Nikfar S, Costei A, Boskovic R, Nulman I, Koren G. Aspirin consumption during the first trimester of pregnancy and congenital anomalies: a meta-analysis. Am J Obstet Gynecol. 2002 Dec;187(6):1623-30.

19. Nørgård B, Puhó E, Czeizel AE, Skriver MV, Sørensen HT. Aspirin use during early pregnancy and the risk of congenital abnormalities: a populationbased case-control study. Am J Obstet Gynecol. 2005 Mar;192(3):922-3.

20. Bates SM, Greer IA, Middeldorp S, Veenstra DL, Prabulos AM, Vandvik PO. VTE, thrombophilia, antithrombotic therapy, and pregnancy: Antithrombotic Therapy and Prevention of Thrombosis, 9th ed: American College of Chest Physicians EvidenceBased Clinical Practice Guidelines. Chest. 2012 Feb;141(2 Suppl):e691S-e736S.

21. Siristatidis CS, Basios G, Pergialiotis V, Vogiatzi P. Aspirin for in vitro fertilisation. Cochrane Database Syst Rev. 201611 3;11:CD004832.

22. Cayla G, Collet JP, Silvain J, Thiefin G, Woimant $F$, Montalescot G. Prevalence and clinical impact of Upper Gastrointestinal Symptoms in subjects treated with low dose aspirin: the UGLA survey. Int $\mathrm{J}$ Cardiol. 2012 Apr 5;156(1):69-75.

23. Sung JJ. Continuation of Low-Dose Aspirin Therapy in Peptic Ulcer Bleeding. Ann Intern Med. 2010 Jan 5;152(1):1.

24. Li CM, Zhernakova A, Engstrand L, Wijmenga C, Brusselaers N, Systematic review with meta-analysis: the risks of proton pump inhibitors during preg- 
nancy. Aliment PharmacolTher. 2020;51(4):410-420.

25. Hastie R, Bergman L, Cluver CA, Wikman A, Hannan NJ, Walker SP, Wikström AK, Tong S, Hesselman S, Proton Pump Inhibitors and Preeclampsia Risk Among 157720 Women. Hypertension. 2019 May;73(5):1097-103.

26. Falck-Ytter Y, Francis CW, Johanson NA, Curley C, Dahl OE, Schulman S, et al. Prevention of VTE in orthopedic surgery patients: Antithrombotic Therapy and Prevention of Thrombosis, 9th ed: American College of Chest Physicians Evidence-Based Clinical Practice Guidelines. Chest. 2012 Feb;141(2 Suppl):e278S-e325S.

27. Dimić N, Stevanović K, Krivokapić B, Kočica MK, Dimić I, Baljozović A. Venska Tromboembolija - Procena Rizika, Profilaksa I Lečenje. Apollinem medicum et aesculapium, 2019;17(3):35-45

28. James AH, Brancazio LR, Price T. Aspirin and reproductive outcomes. ObstetGynecolSurv. 2008 Jan;63(1):49-57.

29. Appleby CE, Barolet A, Ing D, Ross J, Schwartz L, Seidelin P, Silversides C, Horlick E, Contemporary management of pregnancy-related coronary artery dissection: A single-centre experience and literature review. Exp Clin Cardiol. 2009;14(1):e8-e16.

30. Antonijević $N$, Kanjuh V, Zečević R, Obradović $S$, Stojanović B, Mujović N, Živković I, Kočica M, Živković M, Vukčević V. Mogućnosti novih antitrombocitnih I antikoagulantnih lekova u okviru primarne perkutane koronarne intervencije. Balneoklimatologija 2011; 35(1):101-119.

31. Antonijević N, Kanjuh V, Obradović S, Stojanović B, Mujović N, Lazarević S. Novi antitrombocitni lekovi. Budućnost kardiovaskularne terapije. 3. Naučni skup Odbora za kardiovaskularnu patologiju SANU i Srpskog farmakološkog društva. Urednici: Kanjuh V, Gojković Bukarica Lj. 2011. Str 47-55.

32. Jovanovic Lj, Antonijevic N, Novakovic T, Savic N, Terzic B, Zivkovic I, Radovanovic N, Asanin M. Practical Aspects of Monitoring of Antiplatelet Therapy. Semin ThrombHemost. 2016 Nov 8;43(01):01423.

33. Antonijević N, Jovanović Lj, Živković I, Matić D, Jelić D, Kanjuh V. Monitoring i personalizacija antitrombocitne terapije. Bilt Transfuziol 2014;60 $(1-2): 67-72$

34. Medicines.org.uk. 2019. Clopidogrel $75 \mathrm{mg}$ filmcoated tablets - Summary of Product Characteristics (SPC) - (Emc). [online] Available at: https:// www. medicines.org.uk/emc/product/4755/smpc [Accessed 28 December 2019].

35. Santiago-Díaz P, Arrebola-Moreno AL, RamírezHernández JA, Melgares-Moreno R. Platelet antiaggregants in pregnancy. Rev EspCardiol 62 11971198, 2009.

36. Reilly, C.R., Cuesta-Fernandez, A. \&Kayaleh, O.R., Successful gestation and delivery using clopi- dogrel for secondary stroke prophylaxis: a case report and literature review. Arch Gynecol Obstet (2014) 290: 591.

37. De Santis M, De Luca C, Mappa I, Cesari E, Mazza A, Quattrocchi T, Caruso A Clopidogrel Treatment during Pregnancy: A Case Report and a Review of Literature. Intern Med. 2011;50(16):1769-73.

38. Yilmaz S, Sahinkus S, Kilic H, Gunduz H, Akdemir R. Acute Coronary Syndrome During Pregnancy: A Case Report and Literature Review. Turk J Emerg Med. 2016;14(3):135-8. Published 2016 Feb 26.

39. Oliphant CS, Trevarrow BJ, Dobesh PP. Clopidogrel Response Variability: Review of the Literature and Practical Considerations. J Pharm Pract. 2016 Feb;29(1):26-34.

40. Valgimigli M, Bueno H, Byrne RA, Collet J, Costa F, Jeppsson A, et al. 2017 ESC focused update on dual antiplatelet therapy in coronary artery disease developed in collaboration with EACTS. European Heart Journal. 2018 Jan 14;39(3):213-60.

41. Medicines.org.uk. 2019. Brilique $90 \mathrm{mg}$ film coated tablets - Summary of Product Characteristics (SPC) - (Emc). [online] Available at: https:// www. medicines.org.uk/emc/product/5767/smpc [Accessed 28 December 2019].

42. Verbruggen $M$, Mannaerts $D$, Muys J, Jacquemyn Y. Use of tikagrelor in human pregnancy, the first experience. BMJ Case Rep. 2015;2015:bcr2015212217. Published 2015 Nov 25. doi:10.1136/bcr-2015212217

43. Argentiero D, Savonitto S, D'Andrea P, lacovelli F. Ticagrelor and tirofiban in pregnancy and delivery: beyond labels. J Thromb Thrombolysis. 2020 Jan;49(1):145-8.

44. Medicines.org.uk. 2020. Efient $10 \mathrm{mg}$ film-coated tablets - Summary of Product Characteristics (SPC) - (Emc). [online] Available at: https://www. medicines.org.uk/emc/product/6466/smpc [ACcessed 25 March 2020].

45. Tello-Montoliu A, Seecheran NA, Angiolillo DJ. Successful pregnancy and delivery on prasugrel treatment: considerations for the use of dual antiplatelet therapy during pregnancy in clinical practice. J Thromb Thrombolysis. 2013 Oct;36(3):34851.

46. Love BB, Biller J, Gent M. Adverse haematological effects of ticlopidine. Prevention, recognition and management. Drug Saf. 1998 Aug;19(2):89-98.

47. Kam PCA, Nethery CM. The thienopyridine derivatives (platelet adenosine diphosphate receptor antagonists), pharmacology and clinical developments. Anaesthesia. 2003 Jan;58(1):28-35.

48. Ueno M, Masuda H, Nakamura K, Sakata R. Antiplatelet therapy for a pregnant woman with a mechanical aortic valve: report of a case. Surg Today. 2001;31(11):1002-4. 


\title{
Kompleksnost primene peroralnih antitrombocitnih lekova u trudnoći
}

\author{
Nebojša M. Antonijevićc, , Nikola D. Gošnjić́ ${ }^{3}$, Ivan V. Rankovićc, \\ Ljubica M. Jovanović ${ }^{1}$, Ivana D. Veljić ${ }^{1}$, Dragan M. Matić ${ }^{1,2}$, Mladen J. Kočica ${ }^{5,7}$, \\ Milica M. Karadžić Kočica ${ }^{6}$, Branka M. Terzić ${ }^{1}$, Žaklina V. Leković1, Dario D. Jelićn ${ }^{1}$ \\ Vladimir I. Kanjuh ${ }^{7}$ \\ ${ }^{1}$ Klinika za kardiologiju, Klinički centar Srbije, Beograd, Srbija \\ ${ }^{2}$ Medicinski fakultet, Univerzitet u Beogradu, Beograd, Srbija \\ ${ }^{3}$ Katedra za farmakokinetiku i kliničku farmaciju, Farmaceutski fakultet, Univerzitet u Beogradu, Beo- \\ grad, Srbija \\ ${ }^{4}$ Klinika za gastroenterohepatologiju, Klinički centar Srbije, Beograd, Srbija \\ ${ }^{5}$ Urgentni centar, Klinika za kardiohirurgiju, Klinički centar Srbije, Beograd, Srbija \\ ${ }^{6}$ Urgentni centar, Klinika za kardiohirurgiju, Centar za anesteziologiju i reanimatologiju \\ Klinički centar Srbije, Beograd, Srbija \\ ${ }^{7}$ Srpska akademija nauka i umetnosti, Odbor za kardiovaskularnu patologiju, Beograd, Srbija
}

\section{KRATAK SADRŽAJ}

Uvod: Povećanjem starosti trudnica u kliničkoj praksi se nameće potreba za primenom lekova koji su se ranije uglavnom koristili u starijim dobnim grupama.

Antitrombocitni lekovi: Posebno je delikatna primena antitrombocitnih lekova imajući u vidu fokusiranost na sigurnost primene leka kod majke i ploda. Pri tome treba imati na umu fiziološke promene u trudnica, koje uključuju hiperkoagulabilnost krvi i promene u agregaciji trombocita, kao i farmakokinetske alteracije primenjenog leka. Acetilsalicilna kiselina, najpropisivaniji antitrombocitni lek u trudnoći ima relativno dobar sigurnosni profil, kao i efikasnost kada se lek primenjuje u malim dozama. I pored relativne sigurnosti, primena acetilsalicilne kiseline u trudnoći zahteva poseban oprez u odnosu na sam lek, na specifičnost određene trudnoće i klinički status. Za razliku od toga, dokazi o adekvatnom efektu inhibitora P2Y12 receptora ( klopidogrel, prasugrel, tikagrelor i tiklopidin) u trudnica su dosta oskudniji. Prikazi njihove upotrebe u urgentnim slučajevima i kliničkoj praksi su relativno retki, uz isticanje važnosti usklađivanja potrebe za neophodnom primenom ovih lekova u određenim situacijama i saznanja o njihovim efektima.

Zaključak: Optimalna primena antitrombocitnih lekova zahteva sagledavanje njihovih svojstava, specifičnosti trudnoće, kliničkog statusa, predviđenih indikacija, koordinisano lečenje i saradnju multidisciplinarnog tima.

Ključne reči: trudnoća, antitrombocitni lekovi, acetilsalicilna kiselina, P2Y12 antagonisti 